\title{
KEEFEKTIFAN PENJAMINAN MUTU STANDAR PROSES DI SDN KALIURANG 2 KECAMATAN PAKEM KABUPATEN SLEMAN
}

\author{
Patna Sustiwi, Muhyadi \\ SDN Percobaan 3 Yogyakarta, Fakultas Ekonomi Universitas Negeri Yogyakarta \\ patnasustiwi@gmail.com, muhyadi@uny.ac.id
}

\begin{abstract}
Abstrak
Penelitian ini bertujuan untuk mengetahui seberapa efektif penjaminan mutu standar proses dalam aspek perencanaan, pelaksanaan, penilaian, dan pengawasan proses pembelajaran di SDN Kaliurang 2 Kecamatan Pakem, Kabupaten Sleman. Jenis penelitian ini adalah penelitian evaluasi dengan model evaluasi kesenjangan. Unit analisis dalam penelitian ini adalah SDN Kaliurang 2 Kecamatan Pakem, Kabupaten Sleman dengan responden kepala sekolah, guru, dan siswa. Teknik pengumpulan data yang digunakan adalah observasi, dokumentasi, dan wawancara dengan instrumen berupa lembar observasi, ceklis, dan pedoman wawancara.Validitas istrumen menggunakan pertimbangan ahli. Teknik analisis data menggunakan statistik deskriptif. Hasil penelitian ini menunjukkan: (1) perencanaan pembelajaran berada dalam kriteria sangat efektif dengan capaian $85,24 \%$, (2) pelaksanaan proses pembelajaran berada dalam kriteria sangat efektif dengan capaian 88,67\%, (3) penilaian pembelajaran berada dalam kriteria efektif dengan capaian $75,29 \%$, dan (4) pengawasan pembelajaran berada dalam kriteria sangat efektif dengan capaian 85,06\%. Secara umum, penjaminan mutu standar proses di SDN Kaliurang 2 Kecamatan Pakem, Kabupaten Sleman termasuk dalam kriteria sangat efektif dengan capaian 83,56\%.
\end{abstract}

Kata Kunci: keefektifan, penjaminan mutu, standar proses

\section{THE EFFECTIVENESS OF STANDARD PROCESS QUALITY ASSURANCE IN STATE ELEMENTARY SCHOOL KALIURANG 2 PAKEM, SLEMAN REGENCY}

\author{
Patna Sustiwi, Muhyadi \\ SDN Percobaan 3 Yogyakarta, Fakultas Ekonomi Universitas Negeri Yogyakarta \\ patnasustiwi@gmail.com,muhyadi@uny.ac.id
}

\begin{abstract}
This study aims to determine how effective standard process quality assurance in aspects of planning, implementation, assessment, and supervision of the learning process in State Elementary School Kaliurang 2 Pakem, Sleman Regency. This research was an evaluation study with discrepancy evaluation model. The unit of analysis in this study is State Elementary School Kaliurang 2 Pakem, Sleman Regency with respondents were the principal, teachers, and students. Data collection techniques used are observation, documentation, and interviews with instruments such as observation sheets, checklists, and interview guides. The validity of the instrument used expert judgement. Data analysis used descriptive statistics. The results of this study show that: (1) the learning plan is included in the very effective criteria with achievement $85.24 \%$, (2) implementation of the learning process is included in the very effective criteria with achievement $86.67 \%$, (3) the learning assessment is included in the effective criteria with achievement $75.29 \%$, and (4) the instructional supervision is included in the very effective criteria with achievement $85.06 \%$. In general, standard process quality assurance in State Elementary School Kaliurang 2 Pakem, Sleman Regency is included in the very effective criteria with achievement $83.56 \%$.
\end{abstract}

Keywords: effectiveness, quality assurance, standard process 


\section{Pendahuluan}

Mutu atau kualitas telah menjadi isu penting dalam kehidupan, termasuk dalam bidang pendidikan. Pendidikan yang bermutu akan menentukan kualitas sumber daya manusia dan perkembangan suatu bangsa. Pendidikan bermutu merupakan sarana yang penting bagi upaya mencerdaskan kehidupan bangsa dan meraih kehidupan yang lebih baik. Pendidikan bermutu diharapkan mampu mengembangkan potensi diri menjadi insan yang kreatif, mandiri, dan beretos kerja tinggi. Pendidikan bermutu merupakan sarana untuk memberikan bekal kehidupan.

Pendidikan bermutu dapat terwujud dengan keterlibatan segenap komponen bangsa karena pendidikan merupakan tanggung jawab bersama antara orang tua, pemerintah, dan masyarakat. Kesadaran akan pentingnya pendidikan bermutu dalam kelangsungan kehidupan bangsa telah membawa semua pihak yang terlibat mengambil peran aktif demi peningkatan mutu pendidikan.

Pemerintah telah menunjukkan komitmen dalam meningkatkan mutu pendidikan di Indonesia dengan menerbitkan Peraturan Pemerintah Nomor 19 Tahun 2005 tentang Standar Nasional Pendidikan yang telah direvisi dengan terbitnya Peraturan Pemerintah Nomor 32 Tahun 2013. Standar Nasional Pendidikan adalah kriteria minimal tentang sistem pendidikan di seluruh wilayah hukum Negara Kesatuan Republik Indonesia. Standar Nasional Pendidikan meliputi: Standar Kompetensi Lulusan, Standar Isi, Standar Proses, Standar Pendidik dan Tenaga Kependidikan, Standar Sarana dan Prasarana, Standar Pengelolaan, Standar Pembiayaan, dan Standar Penilaian Pendidikan untuk dijadikan acuan bagi sekolah dalam pencapaian mutunya.

Dari delapan standar nasional pendidikan, yang paling erat kaitannya dengan kegiatan pembelajaran dan berpengaruh terhadap kualitas hasil pendidikan adalah standar proses pembelajaran. Dalam Permendiknas Nomor 41 Tahun 2007 pasal 1 ayat (1) disebutkan bahwa standar proses untuk satuan pendidikan dasar dan menengah mencakup perencanaan proses pembelajaran, pelaksanaan proses pembelajaran, penilaian hasil pembelajaran, dan pengawasan proses pembelajaran.

Lembaga pendidikan harus bisa memberikan jaminan mutu terhadap program pendidikan yang akan diberikan kepada peserta didiknya. Seperti yang diamanatkan dalam Peraturan Menteri Pendidikan Nasional Nomor 63 Tahun 2009 pasal 5, bahwa penjaminan mutu pendidikan formal dan nonformal dilaksanakan oleh satuan atau program pendidikan. Pelaksanaan penjaminan mutu pendidikan sangat penting diterapkan dalam kondisi pendidikan di Indonesia karena di satu sisi sekolah diberi kewenangan untuk mengelola pendidikan dan mengembangkan kurikulum sesuai dengan situasi dan kondisi masingmasing, tetapi di sisi lain ada tuntutan standar nasional pendidikan dan persaingan di tingkat global. Kesenjangan mutu yang sangat tinggi antar sekolah dan antar daerah akan terjadi jika tidak ada jaminan mutu pendidikan yang didasarkan pada kriteria tertentu, misalnya standar nasional pendidikan.

Penjaminan mutu merupakan suatu sistem dalam pengelolaan mutu yang di dalamnya terdapat prosedur pengelolaan suatu organisasi yang bersifat komprehensif dan terintegrasi. Tujuan utama dari sistem penjaminan mutu adalah untuk mencegah terjadinya kesalahan dalam proses dengan cara mengupayakan agar setiap langkah yang dilaksanakan diawasi sejak tahap perencanaan. Lembaga Penjaminan Mutu Pendidikan telah mengambil inisiatif untuk memberikan pembekalan dan pendampingan bagi sekolah dalam melaksanakan penjaminan mutu. Kegiatan pembekalan yang diberikan kepada kepala sekolah dan guru diharapkan dapat diaplikasikan dengan baik mulai dari penyusunan dokumen sampai dengan tahap implementasi. Akan tetapi, pengamatan di lapangan menunjukkan bahwa kegiatan penjaminan mutu baru sebatas pada penyusunan dokumen sehingga implementasinya belum optimal. 
Hasil penelitian Raharjo (2012, p. 314) menunjukkan masih adanya berbagai hambatan dalam pemenuhan standar nasional pendidikan. Salah satu hambatan dalam komponen proses pembelajaran adalah belum terpenuhinya target rencana proses pembelajaran. Sementara Kardiyem (2013, p. 18) memaparkan hasil Uji Kompetensi Guru (UKG) yang dilaksanakan pemerintah juga masih menunjukkan hasil yang belum maksimal dan masih jauh dari harapan. Hal tersebut merupakan salah satu indikator masih lemahnya kompetensi guru.

Peran kepala sekolah untuk meningkatkan kompetensi guru, terutama dalam pelaksanaan proses pembelajaran mutlak diperlukan. Jika kepala sekolah melaksanakan fungsi pengawasan secara optimal diharapkan efektifitas pembelajaran dapat tercapai.

Proses pembelajaran merupakan suatu proses yang mengandung serangkaian kegiatan guru dan siswa atas dasar hubungan timbal-balik yang berlangsung dalam situasi edukatif untuk mencapai tujuan yang telah ditetapkan. Interaksi atau hubungan timbal balik antara guru dan siswa ini merupakan syarat utama bagi berlangsungnya proses pembelajaran. Pengamatan di lapangan menunjukkan masih terdapat sebagian guru mendominasi dalam proses pembelajaran sementara siswa pasif sehingga interaksi antara guru dengan siswa dalam proses pembelajaran tidak efektif. Jika proses pembelajaran lebih didominasi oleh guru maka efektifitas pembelajaran tidak akan dapat dicapai. Untuk menciptakan kondisi pembelajaran yang efektif, guru dituntut agar mampu mengelola proses pembelajaran yang memberikan rangsangan kepada siswa agar mau dan mampu belajar.

SDN Kaliurang 2 yang berada di Kaliurang, Hargobinangun, Kecamatan Pakem, Kabupaten Sleman menarik untuk dijadikan objek penelitian karena tidak hanya mengutamakan prestasi akademik akan tetapi pendidikan karakter yang berwawasan lingkungan juga diterapkan dalam proses pembelajaran di sekolah. Pendidik- an berkualitas dan berwawasan lingkungan yang dilaksanakan di SDN Kaliurang 2 Kecamatan Pakem, Kabupaten Sleman ini mendapat apresiasi dari pemerintah dengan diberikannya penghargaan sebagai Sekolah Model Berwawasan Lingkungan Hidup pada tahun 2008. Akreditasi Sekolah yang dilakukan oleh Badan Akreditasi Nasional Sekolah/Madrasah (BAN-S/M) pada tahun 2011 juga menunjukkan hasil yang sangat memuaskan dengan predikat A.

Lembaga Penjaminan Mutu Pendidikan Daerah Istimewa Yogyakarta pada bulan April 2012 melakukan kegiatan pendampingan evaluasi diri sekolah dan sistem penjaminan mutu pendidikan. SDN Kaliurang 2 Kecamatan Pakem, Kabupaten Sleman merupakan salah satu sekolah di Kecamatan Pakem yang telah mengimplementasikan penjaminan mutu pendidikan standar proses melalui pendampingan dari Lembaga Penjaminan Mutu Pendidikan Daerah Istimewa Yogyakarta. Penjaminan mutu pendidikan standar proses di SDN Kaliurang 2 Kecamatan Pakem, Kabupaten Sleman ini dipandang perlu untuk diteliti mengingat belum ada informasi tentang keefektifan dalam pelaksanaannya dibandingkan kriteria yang telah ditetapkan dalam Permendiknas Nomor 41 Tahun 2007.

Komitmen untuk meningkatkan kualitas pendidikan di sekolah ini juga terlihat dari kegigihan kepala sekolah untuk meningkatkan kualifikasi akademik jenjang pascasarjana. Hal ini merupakan unsur keteladanan kepala sekolah dalam membangkitkan semangat para guru untuk meningkatkan kualifikasi akademik dengan menempuh pendidikan jenjang sarjana di luar jam mengajar sehingga saat ini sudah semua guru SDN Kaliurang 2 Kecamatan Pakem, Kabupaten Sleman memiliki kualifikasi pendidikan S1.

\section{Metode Penelitian}

Penelitian ini merupakan penelitian evaluasi tentang keefektifan penjaminan mutu standar proses di SDN Kaliurang 2 Kecamatan Pakem, Kabupaten Sleman. 
Pendekatan yang digunakan adalah pendekatan kuantitatif. Model evaluasi yang digunakan adalah Discrepancy Evaluation Model atau evaluasi model kesenjangan dengan cara membandingkan pengelolaan pembelajaran yang dilaksanakan di SDN Kaliurang 2 dengan kriteria penjaminan mutu standar proses berdasarkan Permendiknas Nomor 41 Tahun 2007. Dengan mengetahui kesenjangan tersebut dapat digunakan untuk menentukan seberapa efektif penjaminan mutu standar proses di SDN Kaliurang 2 Kecamatan Pakem, Kabupaten Sleman.

Penelitian ini dilakukan di SDN Kaliurang 2 Kecamatan Pakem, Kabupaten Sleman. Penelitian dimulai tanggal 27 September 2013 sampai dengan tanggal 27 Desember 2013.

Unit analisis dalam penelitian ini adalah SDN Kaliurang 2 Kecamatan Pakem, Kabupaten Sleman. Responden dalam penelitian ini adalah satu orang kepala sekolah, 7 orang guru dan 28 siswa siswa SDN Kaliurang 2 Kecamatan Pakem, Kabupaten Sleman.

Teknik pengumpulan data yang digunakan pada penelitian ini adalah observasi, wawancara, dan dokumentasi. Instrumen pengumpulan data yang digunakan dalam penelitian ini adalah lembar observasi, pedoman wawancara, dan ceklis pencermatan dokumen.

Validitas instrumen dalam penelitian ini menggunakan expert judgement atau pendapat ahli. Instrumen penelitian yang telah disusun dimintakan pendapat ahli untuk diberikan saran perbaikan kemudian diberikan keputusan apakah instrumen sudah layak digunakan atau perlu diperbaiki.

Instrumen yang digunakan dalam penelitian ini diambil dari Permendiknas Nomor 41 Tahun 2007. Dengan demikian, uji reliabilitas tidak dilakukan terhadap instrumen penelitian.

Data yang diperoleh dianalisis dengan statistik deskriptif dalam bentuk skor rerata (M), simpangan baku (SD), dan kategorisasi. Kriteria penilaian ditentukan berdasarkan besarnya standar deviasi atau simpangan baku ideal (SDi) dan skor rerata atau mean ideal (Mi) pada setiap variabel instrumen penelitian.

Kriteria kecenderungan yang digunakan untuk mengungkap kondisi masingmasing aspek menggunakan rumus yang dikembangkan oleh Direktorat Pembinaan SMA (2010, p. 60). Pengubahan data kuantitatif menjadi kualitatif digunakan empat kriteria yaitu:

Tabel 1. Klasifikasi Keefektifan Penjaminan Mutu Standar Proses

\begin{tabular}{cc}
\hline Rentang Skor & Kriteria \\
\hline $\mathrm{Mi}-3 \mathrm{SDi} \leq \mathrm{X} \leq \mathrm{Mi}-1,5 \mathrm{SDi}$ & Kurang \\
efektif \\
$\mathrm{Mi}-1,5 \mathrm{SDi}<\mathrm{X} \leq \mathrm{Mi}+0 \mathrm{SDi}$ & Cukup efektif \\
$\mathrm{Mi}+$ 0 SDi $<\mathrm{X} \leq \mathrm{Mi}+1,5 \mathrm{SDi}$ & Efektif \\
$\mathrm{Mi}+1,5 \mathrm{SDi}<\mathrm{X} \leq \mathrm{Mi}+3 \mathrm{SDi}$ & Sangat efektif \\
\hline
\end{tabular}

Rata-rata ideal dan simpangan baku ideal dapat dihitung dengan menggunakan rumus :

$M i=\frac{N i t+N i r}{2}$

$S D i=\frac{N i t-N i r}{6}$

Keterangan:

$\mathrm{M} \quad=$ Rata-rata ideal

Sdi = Simpangan baku ideal

Nit = Nilai tertinggi ideal

Nir = Nilai terendah ideal

$\mathrm{X}=$ Skor yang dicapai indikator

\section{Hasil Penelitian dan Pembahasan}

Aspek Perencanaan Pembelajaran

Perencanaan pembelajaran disusun oleh guru SDN Kaliurang 2 Kecamatan Pakem Kabupaten Sleman berdasarkan Standar Isi yang selanjutnya dikembangkan dalam Kurikulum Tingkat Satuan Pendidikan. Kegiatan perencanaan pembelajaran meliputi penyusunan silabus dan rencana pelaksanaan pembelajaran.

Berikut data perencanaan pembelajaran untuk masing-masing indikator:

\section{Mengkaji Standar Kompetensi}

Pada indikator ini terdapat empat kriteria, yaitu: (1) menganalisiss standar 
kompetensi berdasarkan tuntutan SKL, (2) mengkaji hierarkhi konsep disiplin ilmu dan tingkat kesulitan materi, (3) mengkaji keterkaitan antarstandar kompetensi dalam mata pelajaran, dan (4) mengkaji keterkaitan standar kompetensi antar mata pelajaran.

Rata-rata ideal dan simpangan baku ideal untuk menentukan keefektifan mengkaji standar kompetensi adalah sebagai berikut:

$M i=\frac{N i t+N i r}{2}=\frac{16+4}{2}=10$

$S D i=\frac{N i t-N i r}{6}=\frac{16-4}{6}=2$

Dari hasil perhitungan rata-rata ideal dan simpangan baku ideal tersebut maka klasifikasi keefektifan mengkaji standar kompetensi disajikan pada Tabel 2.

Tabel 2. Klasifikasi Keefektifan Mengkaji Standar Kompetensi

\begin{tabular}{|c|c|c|}
\hline Perhitungan & Skor & Kriteria \\
\hline Mi $-3 S D i \leq X \leq$ Mi-1,5SDi & $4,00-7,00$ & Kurang efektif \\
\hline Mi-1,5SDi<X $\leq \mathrm{Mi}+0 \mathrm{SDi}$ & $7,01-10,00$ & up efektif \\
\hline $\mathrm{Mi}+0 \mathrm{SDi}<\mathrm{X} \leq \mathrm{Mi}+1,5 \mathrm{SDi}$ & $10,01-13,00$ & Efektif \\
\hline $\mathrm{Mi}+1,5 \mathrm{SDi}<\mathrm{X} \leq \mathrm{Mi}+3 \mathrm{SDi}$ & $13,01-16,00$ & Sangat efektif \\
\hline
\end{tabular}

Data hasil penelitian menunjukkan terdapat $28,60 \%$ guru mempunyai skor antara $7,01-10,00,57,10 \%$ guru mempunyai skor antara $10,01-13,00$, dan $14,30 \%$ guru mempunyai skor antara 13,01-16,00.

Tabel 3. Keefektifan Mengkaji Standar Kompetensi

\begin{tabular}{cccc}
\hline No & Skor & Kriteria & Persentase \\
\hline 1 & $4,00-7,00$ & Kurang efektif & 0,00 \\
2 & $7,01-10,00$ & Cukup efektif & 28,60 \\
3 & $10,01-13,00$ & Efektif & 57,10 \\
4 & $13,01-16,00$ & Sangat efektif & 14,30 \\
& Jumlah & & 100 \\
\hline
\end{tabular}

Berdasarkan tabel 3 dapat diketahui bahwa dalam mengkaji standar kompetensi, terdapat $28,60 \%$ guru berada dalam kriteria cukup efektif, $57,10 \%$ berada dalam kriteria efektif, dan $14,30 \%$ berada dalam kriteria sangat efektif. Sedangkan nilai ratarata (mean) sebesar 12,14 menunjukkan bahwa kemampuan guru dalam mengkaji standar kompetensi dalam kriteria efektif.

Mengkaji Kompetensi Dasar

Pada indikator ini terdapat tiga kriteria, yaitu: (1) mengkaji urutan kompetensi dasar berdasarkan hierarkhi konsep disiplin ilmu dan karakteristik siswa, (2) mengkaji keterkaitan antar kompetensi dasar, dan (3) mengkaji keterkaitan kompetensi dasar antar mata pelajaran. Data hasil penelitian menunjukkan terdapat $85,70 \%$ guru mempunyai skor antara 7,51-9,75 dan $14,30 \%$ mempunyai skor antara 9,76-12,00.

Tabel 4. Keefektifan Mengkaji Kompetensi Dasar

\begin{tabular}{cccc}
\hline No & Skor & Kriteria & Persentase \\
\hline 1 & $3,00-5,25$ & Kurang efektif & 0,00 \\
2 & $5,26-7,50$ & Cukup efektif & 0,00 \\
3 & $7,51-9,75$ & Efektif & 85,70 \\
4 & $9,76-12,00$ & Sangat efektif & 14,30 \\
& Jumlah & & 100 \\
\hline
\end{tabular}

Berdasarkan Tabel 4 dapat diketahui bahwa dalam mengkaji kompetensi dasar, terdapat $85,70 \%$ guru berada dalam kriteria efektif dan $14,30 \%$ guru berada dalam kriteria sangat efektif. Sedangkan nilai rata-rata (mean) sebesar 8,86 menunjukkan bahwa kemampuan guru dalam mengkaji kompetensi dasar termasuk dalam kriteria efektif.

\section{Mengidentifikasi Materi}

Pada indikator ini terdapat tujuh kriteria, yaitu: (1) mempertimbangkan potensi peserta didik, (2) mempertimbangkan tingkat perkembangan peserta didik, (3) mempertimbangkan kebermanfaatan bagi peserta didik, (4) mempertimbangkan struktur keilmuan, (5) mempertimbangkan materi pelajaran, (6) mempertimbangkan relevansi, (7) mempertimbangkan alokasi waktu. Data hasil penelitian menunjukkan terdapat $42,90 \%$ guru mempunyai skor antara $17,51-22,75$ dan $57,10 \%$ mempunyai skor antara 22,76-28,00.

Berdasarkan Tabel 5 dapat diketahui bahwa dalam mengidentifikasi materi, terdapat $42,90 \%$ guru berada dalam kriteria efektif dan $57,10 \%$ guru berada dalam kri- 
teria sangat efektif. Sedangkan nilai ratarata (mean) sebesar 23,57 menunjukkan bahwa kemampuan guru dalam mengidentifikasi materi termasuk dalam kriteria sangat efektif.

Tabel 5. Keefektifan Mengidentifikasi Materi

\begin{tabular}{cccc}
\hline No & Skor & Kriteria & Persentase \\
\hline 1 & $7,00-12,25$ & Kurang efektif & 0,00 \\
2 & $12,25-17,50$ & Cukup efektif & 0,00 \\
3 & $17,51-22,75$ & Efektif & 42,90 \\
4 & $22,76-28,00$ & Sangat efektif & 57,10 \\
& Jumlah & & 100 \\
\hline
\end{tabular}

Merumuskan Indikator

Pada indikator ini terdapat lima kriteria, yaitu: (1) setiap kompetensi dasar dikembangkan menjadi beberapa indikator, (2) setiap indikator menggunakan kata kerja operasional yang dapat diukur, (3) tingkat tahap pikir dalam indikator lebih rendah atau setara dengan kata kerja dalam kompetensi dasar, (4) merumuskan indikator berdasarkan prinsip pengembangan indikator antara lain Urgensi, Kontinuitas, Relevansi dan Kontekstual, dan (5) keseluruhan indikator dalam satu kompetensi dasar merupakan tanda-tanda dan perilaku untuk pencapaian kompetensi. Data hasil penelitian menunjukkan terdapat $28,60 \%$ guru mempunyai skor antara $12,51-16,25$ dan $71,40 \%$ mempunyai skor antara 16,26-20,00.

Tabel 6. Keefektifan Merumuskan Indikator

\begin{tabular}{cccc}
\hline No & Skor & Kriteria & Persentase \\
\hline 1 & $5,00-8,75$ & Kurang efektif & 0,00 \\
2 & $8,76-12,50$ & Cukup efektif & 0,00 \\
3 & $12,51-16,25$ & Efektif & 28,60 \\
4 & $16,26-20,00$ & Sangat efektif & 71,40 \\
& Jumlah & & 100 \\
\hline
\end{tabular}

Berdasarkan Tabel 6 dapat diketahui bahwa dalam merumuskan indikator, terdapat $28,60 \%$ guru berada dalam kriteria efektif dan $71,40 \%$ guru berada dalam kriteria sangat efektif. Sedangkan nilai ratarata (mean) sebesar 16,86 menunjukkan bahwa kemampuan guru dalam merumuskan indikator termasuk dalam kriteria sangat efektif.

\section{Mengembangkan Kegiatan Pembelajaran}

Pada indikator ini terdapat lima kriteria, yaitu: (1) kegiatan pembelajaran bisa membantu guru dalam melaksanakan proses pembelajaran secara profesional, (2) kegiatan pembelajaran yang dipilih memuat rangkaian kegiatan yang dilakukan peserta didik untuk mencapai kompetensi, (3) urutan kegiatan pembelajaran sesuai dengan hierarki konsep materi pembelajaran, (4) kegiatan pembelajaran mencerminkan pengelolaan pengalaman belajar peserta didik yaitu kegiatan siswa dan materi, dan (5) mencerminkan tuntutan standar proses dan model pembelajaran. Data hasil penelitian menunjukkan terdapat $42,90 \%$ guru mempunyai skor antara 12,51 16,25 dan $57.10 \%$ mempunyai skor antara $16,26-20,00$.

Tabel 7. Keefektifan Mengembangkan Kegiatan Pembelajaran

\begin{tabular}{cccc}
\hline No & Skor & Kriteria & Persentase \\
\hline 1 & $5,00-8,75$ & Kurang efektif & 0,00 \\
2 & $8,76-12,50$ & Cukup efektif & 0,00 \\
3 & $12,51-16,25$ & Efektif & 42,90 \\
4 & $16,26-20,00$ & Sangat efektif & 57,10 \\
& Jumlah & & 100 \\
\hline
\end{tabular}

Berdasarkan Tabel 7 dapat diketahui bahwa dalam mengembangkan kegiatan pembelajaran, terdapat $42,90 \%$ guru berada dalam kriteria kriteria efektif dan 57,10\% berada dalam kriteria sangat efektif. Sedangkan nilai rata-rata (mean) sebesar 16,86 menunjukkan kemampuan guru dalam mengembangkan kegiatan pembelajaran termasuk sangat efektif.

\section{Menentukan Jenis Penilaian}

Pada indikator ini terdapat enam kriteria, yaitu: (1) jenis penilaian berfungsi menilai ketercapaian indikator yang telah dirumuskan, (2) jenis penilaian menggunakan acuan kriteria, (3) penilaian mencerminkan sistem penilaian berkelanjutan, (4) hasil penilaian bisa dianalisis untuk menentukan tindak lanjut, (5) jenis penilaian 
sesuai dengan pengalaman belajar dalam kegiatan pembelajaran, dan (6) setiap indikator ditetapkan jenis penilaiannya.

Data hasil penelitian menunjukkan terdapat $57,10 \%$ guru mempunyai skor antara $15,01-19,50$ dan $42,90 \%$ mempunyai skor antara 19,51-24,00.

Tabel 8. Keefektifan Menentukan Jenis Penilaian

\begin{tabular}{cccc}
\hline No & Skor & Kriteria & Persentase \\
\hline 1 & $6,00-10,50$ & Kurang efektif & 0,00 \\
2 & $10,51-15,00$ & Cukup efektif & 0,00 \\
3 & $15,01-19,50$ & Efektif & 57,10 \\
4 & $19,51-24,00$ & Sangat efektif & 42,90 \\
& Jumlah & & 100 \\
\hline
\end{tabular}

Berdasarkan tabel 8 dapat diketahui bahwa dalam menentukan jenis penilaian, terdapat $57,10 \%$ guru berada dalam kriteria efektif dan $42,90 \%$ guru berada dalam kriteria sangat efektif. Sedangkan nilai ratarata (mean) sebesar 19,29 menunjukkan bahwa kemampuan guru dalam menentukan jenis penilaian termasuk kriteria efektif.

\section{Menentukan Alokasi Waktu}

Pada indikator ini terdapat dua kriteria, yaitu: (1) penentuan alokasi waktu berdasarkan jumlah minggu efektif dan alokasi waktu mata pelajaran dan (2) penentuan alokasi waktu dalam silabus hanya merupakan perkiraan waktu rerata yang dibutuhkan oleh peserta didik yang beragam. Data hasil penelitian menunjukkan terdapat $100 \%$ guru mempunyai skor antara 6,51-8,00.

Tabel 9. Keefektifan Menentukan Alokasi Waktu

\begin{tabular}{cccc}
\hline No & Skor & Kriteria & Persentase \\
\hline 1 & $2,00-3,50$ & Kurang efektif & 0,00 \\
2 & $3,51-5,00$ & Cukup efektif & 0,00 \\
3 & $5,01-6,50$ & Efektif & 0,00 \\
4 & $6,51-8,00$ & Sangat efektif & 100 \\
& Jumlah & & 100 \\
\hline
\end{tabular}

Berdasarkan tabel 9 dapat diketahui bahwa dalam menentukan alokasi waktu, $100 \%$ guru berada dalam kriteria sangat efektif. Nilai rata-rata (mean) sebesar 7,00 juga menunjukkan bahwa kemampuan guru dalam menentukan alokasi waktu termasuk dalam kriteria sangat efektif.

\section{Menentukan Sumber Belajar}

Pada indikator ini terdapat dua kriteria, yaitu: (1) sumber belajar bervariasi dapat berupa media cetak dan elektronik, nara sumber, serta lingkungan fisik, alam, sosial, dan budaya dan (2) penentuan sumber belajar berdasarkan standar kompetensi dan kompetensi dasar serta materi pokok, kegiatan pembelajaran, dan indikator pencapaian kompetensi. Data hasil penelitian menunjukkan terdapat $28,60 \%$ guru mempunyai skor antara 5,01-6,50 dan $71,40 \%$ mempunyai skor antara $6,51-8,00$.

Tabel 10. Keefektifan Menentukan Sumber Belajar

\begin{tabular}{cccc}
\hline No & Skor & Kriteria & Persentase \\
\hline 1 & $2,00-3,50$ & Kurang efektif & 0,00 \\
2 & $3,51-5,00$ & Cukup efektif & 0,00 \\
3 & $5,01-6,50$ & Efektif & 28,60 \\
4 & $6,51-8,00$ & Sangat efektif & 71,40 \\
& Jumlah & & 100 \\
\hline
\end{tabular}

Berdasarkan tabel 10 dapat diketahui bahwa dalam menentukan sumber belajar, terdapat $28,60 \%$ guru berada dalam kriteria efektif dan $71,40 \%$ guru berada dalam kriteria sangat efektif. Sedangkan nilai ratarata (mean) sebesar 7,14 menunjukkan bahwa kemampuan guru dalam menentukan sumber belajar termasuk dalam kriteria sangat efektif.

\section{Mengisi Identitas}

Pada indikator ini terdapat dua kriteria, yaitu: (1) mencantumkan mata pelajaran yang akan diajarkan dan (2) mengisi kolom kelas dan semester. Data hasil penelitian menunjukkan terdapat $100 \%$ guru mempunyai skor antara 6,51-8,00.

Tabel 11. Keefektifan Mengisi Identitas

\begin{tabular}{cccc}
\hline No & Skor & Kriteria & Persentase \\
\hline 1 & $2,00-3,50$ & Kurang efektif & 0,00 \\
2 & $3,51-5,00$ & Cukup efektif & 0,00 \\
3 & $5,01-6,50$ & Efektif & 0,00 \\
4 & $6,51-8,00$ & Sangat efektif & 100 \\
& Jumlah & & 100 \\
\hline
\end{tabular}


Berdasarkan Tabel 11 dapat diketahui bahwa dalam mengisi identitas, $100 \%$ guru berada dalam kriteria sangat efektif. Nilai rata-rata (mean) sebesar 8,00 juga menunjukkan bahwa kemampuan guru dalam mengisi identitas termasuk dalam kriteria sangat efektif.

\section{Menentukan SK/KD}

Pada indikator ini terdapat dua kriteria, yaitu: (1) standar kompetensi yang dipilih sesuai dengan silabus dan (2) kompetensi dasar yang dipilih sesuai dengan silabus. Data hasil penelitian menunjukkan terdapat $100 \%$ guru mempunyai skor antara $6,51-8,00$.

Tabel 12. Keefektifan Menentukan SK/KD

\begin{tabular}{cccc}
\hline No & Skor & Kriteria & Persentase \\
\hline 1 & $2,00-3,50$ & Kurang efektif & 0,00 \\
2 & $3,51-5,00$ & Cukup efektif & 0,00 \\
3 & $5,01-6,50$ & Efektif & 0,00 \\
4 & $6,51-8,00$ & Sangat efektif & 100 \\
& Jumlah & & 100 \\
\hline
\end{tabular}

Berdasarkan Tabel 12 dapat diketahui bahwa dalam menentukan standar kompetensi/kompetensi dasar, $100 \%$ guru berada dalam kriteria sangat efektif. Nilai rata-rata (mean) sebesar 8,00 juga menunjukkan bahwa kemampuan guru dalam menentukan standar kompetensi/kompetensi dasar termasuk dalam kriteria sangat efektif.

\section{Menentukan Tujuan dan Indikator}

Pada indikator ini terdapat dua kriteria, yaitu: (1) rumusan tujuan pembelajaran menggambarkan indikator yang hendak dicapai dan (2) indikator yang dipilih sesuai dengan silabus. Data hasil penelitian menunjukkan terdapat $100 \%$ guru mempunyai skor antara 6,51-8,00.

Tabel 13. Keefektifan Menentukan Tujuan dan Indikator

\begin{tabular}{cccc}
\hline No & Skor & Kriteria & Persentase \\
\hline 1 & $2,00-3,50$ & Kurang efektif & 0,00 \\
2 & $3,51-5,00$ & Cukup efektif & 0,00 \\
3 & $5,01-6,50$ & Efektif & 0,00 \\
4 & $6,51-8,00$ & Sangat efektif & 100 \\
& Jumlah & & 100 \\
\hline
\end{tabular}

Berdasarkan Tabel 13 dapat diketahui bahwa dalam menentukan tujuan dan indikator, $100 \%$ guru berada dalam kriteria sangat efektif. Nilai rata-rata (mean) sebesar 7,57 juga menunjukkan bahwa kemampuan guru dalam menentukan tujuan dan indikator termasuk dalam kriteria sangat efektif.

\section{Menentukan Materi dan Alokasi Waktu}

Pada indikator ini terdapat dua kriteria, yaitu: (1) materi pelajaran sesuai standar kompetensi, kompetensi dasar, dan indikator yang terdapat dalam silabus dan (2) alokasi waktu didasarkan pada perkiraan waktu rerata untuk menguasai satu kompetensi dasar yang dibutuhkan oleh peserta didik yang beragam. Data hasil penelitian menunjukkan terdapat $14.30 \%$ guru mempunyai skor antara 3,51-5,00, $42,85 \%$ guru mempunyai skor antara 5,01 6,50 , dan $42,85 \%$ guru mempunyai skor antara 6,51-8.,00

Tabel 14. Keefektifan Menentukan Materi dan Alokasi Waktu

\begin{tabular}{cccc}
\hline No & Skor & Kriteria & Persentase \\
\hline 1 & $2,00-3,50$ & Kurang efektif & 0,00 \\
2 & $3,51-5,00$ & Cukup efektif & 14,30 \\
3 & $5,01-6,50$ & Efektif & 42,85 \\
4 & $6,51-8,00$ & Sangat efektif & 42,85 \\
& Jumlah & & 100 \\
\hline
\end{tabular}

Berdasarkan tabel 14 dapat diketahui bahwa dalam menentukan materi dan alokasi waktu, terdapat $14,30 \%$ guru berada dalam kriteria cukup efektif, 42,85\% guru berada dalam kriteria efektif, dan 42,85\% guru berada dalam kriteria sangat efektif. Sedangkan nilai rata-rata (mean) sebesar 6,71 menunjukkan bahwa kemampuan guru dalam menentukan materi dan alokasi waktu termasuk dalam kriteria sangat efektif.

\section{Menentukan Metode Pembelajaran}

Pada indikator ini terdapat dua kriteria, yaitu: (1) metode pembelajaran berdasarkan indikator yang akan dicapai, materi pembelajaran dan sumber belajar yang tersedia dan (2) metode pembelajaran sudah bervariasi sesuai materi pembelajaran 
dan indikator yang akan dicapai. Data hasil penelitian menunjukkan terdapat $28,60 \%$ guru mempunyai skor antara 5,01-6,50, dan $71,40 \%$ mempunyai skor antara $6,51-8,00$.

Tabel 15. Keefektifan Menentukan Metode Pembelajaran

\begin{tabular}{cccc}
\hline No & Skor & Kriteria & Persentase \\
\hline 1 & $2,00-3,50$ & Kurang efektif & 0,00 \\
2 & $3,51-5,00$ & Cukup efektif & 0,00 \\
3 & $5,01-6,50$ & Efektif & 28,60 \\
4 & $6,51-8,00$ & Sangat efektif & 71,40 \\
& Jumlah & & 100 \\
\hline
\end{tabular}

Berdasarkan Tabel 15 dapat diketahui bahwa dalam menentukan metode pembelajaran, terdapat $28,60 \%$ guru berada dalam kriteria efektif dan $71,40 \%$ guru berada dalam kriteria sangat efektif. Nilai ratarata (mean) sebesar 7,29 menunjukkan bahwa kemampuan guru dalam menentukan metode pembelajaran termasuk dalam kriteria sangat efektif.

\section{Merumuskan Langkah Pembelajaran}

Pada indikator ini terdapat tiga kriteria, yaitu: (1) kegiatan awal berisi tentang kegiatan appersepsi, (2) kegiatan inti berisi kegiatan pembelajaran yang dilakukan siswa selama kegiatan pembelajaran berlangsung, dan (3) kegiatan penutup berisi tentang penyimpulan kegiatan yang telah dilakukan, evaluasi formatif, maupun pemberian tugas untuk dikerjakan siswa. Data hasil penelitian menunjukkan terdapat $100 \%$ guru mempunyai skor antara 9,76-12,00.

Tabel 16. Keefektifan Merumuskan Langkah-langkah Pembelajaran

\begin{tabular}{cccc}
\hline No & Skor & Kriteria & Persentase \\
\hline 1 & $3,00-5,25$ & Kurang efektif & 0,00 \\
2 & $5,26-7,50$ & Cukup efektif & 0,00 \\
3 & $7,51-9,75$ & Efektif & 0,00 \\
4 & $9,76-12,00$ & Sangat efektif & 100 \\
& Jumlah & & 100 \\
\hline
\end{tabular}

Berdasarkan tabel 16 dapat diketahui bahwa dalam merumuskan langkah-langkah pembelajaran, terdapat $100 \%$ guru berada dalam kriteria sangat efektif. Nilai ratarata (mean) sebesar 11,29 juga menunjuk- kan bahwa kemampuan guru dalam merumuskan langkah-langkah pembelajaran termasuk dalam kriteria sangat efektif.

\section{Menentukan Alat dan Sumber Bahan}

Pada indikator ini terdapat dua kriteria, yaitu: (1) alat dan sumber bahan ajar didasarkan pada standar kompetensi, kompetensi dasar, materi pokok/pembelajaran, kegiatan pembelajaran, dan indikator pencapaian kompetensi dan (2) sumber bahan ajar bervariasi.

Data hasil penelitian menunjukkan terdapat $28,60 \%$ guru mempunyai skor antara 5,01-6,50 dan $71,40 \%$ guru mempunyai skor antara 6,51-8,00.

Tabel 17. Keefektifan Menentukan Alat dan Sumber Bahan

\begin{tabular}{cccc}
\hline No & Skor & Kriteria & Persentase \\
\hline 1 & $2,00-3,50$ & Kurang efektif & 0,00 \\
2 & $3,51-5,00$ & Cukup efektif & 0,00 \\
3 & $5,01-6,50$ & Efektif & 28,60 \\
4 & $6,51-8,00$ & Sangat efektif & 71,40 \\
& Jumlah & & 100 \\
\hline
\end{tabular}

Berdasarkan Tabel 17 dapat diketahui bahwa dalam menentukan alat dan sumber bahan, terdapat $28,60 \%$ guru berada dalam kriteria efektif dan $71,40 \%$ guru berada dalam kriteria sangat efektif. Nilai rata-rata (mean) sebesar 7,14 menunjukkan bahwa kemampuan guru dalam menentukan alat dan sumber bahan termasuk dalam kriteria sangat efektif.

\section{Menentukan Jenis Penilaian}

Pada indikator ini terdapat empat kriteria, yaitu: (1) jenis penilaian dan instrumen yang digunakan tepat untuk menilai ketercapaian indikator, (2) jenis penilaian dipilih berdasarkan acuan kiteria, (3) mencantumkan Kriteria Ketuntasan Minimal KD, dan (4) mencantumkan teknik penskoran. Data hasil penelitian menunjukkan terdapat $57,10 \%$ guru mempunyai skor antara 10,01-13,00 dan 42.90\% mempunyai skor antara 13,01-16,00.

Berdasarkan Tabel 18 dapat diketahui bahwa dalam menentukan jenis penilaian, terdapat $57,10 \%$ guru berada dalam kriteria efektif dan $42,90 \%$ guru berada 
dalam kriteria sangat efektif. Nilai rata-rata (mean) sebesar 13,00 me-nunjukkan bahwa kemampuan guru dalam menentukan jenis penilaian berada dalam kriteria efektif.

Tabel 18. Keefektifan Menentukan Jenis Penilaian

\begin{tabular}{cccc}
\hline No & Skor & Kriteria & Persentase \\
\hline 1 & $4,00-7,00$ & Kurang efektif & 0,00 \\
2 & $7,01-10,00$ & Cukup efektif & 0,00 \\
3 & $10,01-13,00$ & Efektif & 57,10 \\
4 & $13,01-16,00$ & Sangat efektif & 42,90 \\
& Jumlah & & 100 \\
\hline
\end{tabular}

Aspek Pelaksanaan Proses Pembelajaran

Berikut data pelaksanaan proses pembelajaran untuk masing-masing indikator:

\section{Membuka Kegiatan Pembelajaran}

Pada indikator ini terdapat lima kriteria, yaitu: (1) menarik perhatian siswa, (2) memberikan motivasi awal, (3) memberikan apersepsi, (4) me-nyampaikan tujuan pembelajaran, dan (5) memberikan acuan bahan belajar. Data hasil penelitian menunjukkan terdapat $28,60 \%$ guru mempunyai skor antara 12,51-16,25 dan 71,40\% mempunyai skor antara 16,26-20,00.

Tabel 19. Tabel 19. Keefektifan Membuka Kegiatan Pembelajaran

\begin{tabular}{cccc}
\hline No & Skor & Kriteria & Persentase \\
\hline 1 & $5,00-8,75$ & Kurang efektif & 0,00 \\
2 & $8,76-12,50$ & Cukup efektif & 0,00 \\
3 & $12,51-16,25$ & Efektif & 28,60 \\
4 & $16,26-20,00$ & Sangat efektif & 71,40 \\
& Jumlah & & 100 \\
\hline
\end{tabular}

Berdasarkan Tabel 19 dapat diketahui bahwa dalam membuka kegiatan pembelajaran, terdapat $28,60 \%$ guru berada dalam kriteria efektif dan $71,40 \%$ guru berada dalam kriteria sangat efektif. Nilai rata-rata (mean) sebesar 18,14 menunjukkan bahwa kemampuan guru dalam membuka kegiatan pembelajaran termasuk dalam kriteria sangat efektif.

\section{Sikap Guru dalam Proses Pembelajaran}

Pada indikator ini terdapat empat kriteria, yaitu: (1) artikulasi suara jelas, (2) variasi gerakan tidak mengganggu perhatian, (3) antusias menyampaikan bahan ajar, dan (4) posisi mengajar tidak terpaku di satu tempat. Data hasil penelitian menunjukkan terdapat $28,60 \%$ guru mempunyai skor $10,01-13,00$ dan $71,40 \%$ guru mempunyai skor antara 13,01-16,00.

Tabel 20. Keefektifan Sikap Guru dalam Proses Pembelajaran

\begin{tabular}{cccc}
\hline No & Skor & Kriteria & Persentase \\
\hline 1 & $4,00-7,00$ & Kurang efektif & 0,00 \\
2 & $7,01-10,00$ & Cukup efektif & 0,00 \\
3 & $10,01-13,00$ & Efektif & 28,60 \\
4 & $13,01-16,00$ & Sangat efektif & 71,40 \\
& Jumlah & & 100 \\
\hline
\end{tabular}

Berdasarkan Tabel 20 dapat diketahui bahwa sikap guru dalam proses pembelajaran, terdapat $28,60 \%$ guru berada dalam kriteria efektif dan $71,40 \%$ guru berada dalam kriteria sangat efektif. Nilai ratarata (mean) sebesar 14,86 menunjukkan bahwa sikap guru dalam proses pembelajaran sangat efektif.

\section{Penguasaan Materi Pembelajaran}

Pada indikator ini terdapat empat kriteria, yaitu: (1) materi pembelajaran disajikan sesuai dengan langkah-langkah yang direncanakan dalam RPP, (2) menyampaikan materi pembelajaran dengan jelas, (3) memberikan contoh dengan jelas, dan (4) memiliki wawasan yang luas terkait materi pembelajaran atau bahan ajar. Data hasil penelitian menunjukkan terdapat $100 \%$ guru mempunyai skor antara $13,01-16,00$.

Tabel 21. Keefektifan Penguasaan Materi Pembelajaran

\begin{tabular}{cccc}
\hline No & Skor & Kriteria & Persentase \\
\hline 1 & $4,00-7,00$ & Kurang efektif & 0,00 \\
2 & $7,01-10,00$ & Cukup efektif & 0,00 \\
3 & $10,01-13,00$ & Efektif & 0,00 \\
4 & $13,01-16,00$ & Sangat efektif & 100 \\
& Jumlah & & 100 \\
\hline
\end{tabular}

Berdasarkan Tabel 21 dapat diketahui bahwa dalam penguasaan materi pembelajaran, $100 \%$ guru berada dalam kriteria sangat efektif. Nilai rata-rata (mean) sebe- 
sar 15,57 juga menunjukkan bahwa kemampuan guru dalam penguasaan materi pembelajaran termasuk dalam kriteria sangat efektif.

\section{Pelaksanaan Kegiatan Belajar Mengajar}

Pada indikator ini terdapat empat kriteria, yaitu: (1) metode yang digunakan sesuai dengan bahan belajar yang disampaikan, (2) penyajian materi pembelajaran sesuai dengan tujuan/indikator yang telah ditetapkan, (3) terampil dalam menanggapi dan merespon pertanyaan siswa, dan (4) menggunakan waktu sesuai dengan alokasi. Data hasil penelitian menunjukkan $42,90 \%$ guru mempunyai skor antara 10,01 13,00 dan $57,10 \%$ guru mempunyai skor antara 13,01-16,00.

Tabel 22. Keefektifan Pelaksanaan Kegiatan Belajar Mengajar

\begin{tabular}{cccc}
\hline No & Skor & Kriteria & Persentase \\
\hline 1 & $4,00-7,00$ & Kurang efektif & 0,00 \\
2 & $7,01-10,00$ & Cukup efektif & 0,00 \\
3 & $10,01-13,00$ & Efektif & 42,90 \\
4 & $13,01-16,00$ & Sangat efektif & 57,10 \\
& Jumlah & & 100 \\
\hline
\end{tabular}

Berdasarkan Tabel 22 dapat diketahui bahwa dalam pelaksanaan kegiatan belajar mengajar, 42,90\% guru berada dalam krite-ria efektif dan $57,10 \%$ guru berada dalam kriteria sangat efektif. Nilai rata-rata (mean) sebesar 14,43 menunjukkan bahwa kemampuan guru dalam pelaksanaan kegiatan belajar mengajar termasuk dalam kriteria sangat efektif.

\section{Penggunaan Media Pembelajaran}

Pada indikator ini terdapat empat kriteria, yaitu: (1) memperhatikan prinsipprinsip penggunaan media, (2) menggunakan media yang sesuai dengan materi, (3) terampil dalam menggunakan media pembelajaran, dan (4) media pembelajaran yang digunakan dapat membantu meningkatkan perhatian siswa. Data hasil penelitian menunjukkan 14,30\% guru mempunyai skor antara $7,01-10,00,14,30 \%$ guru mempunyai skor antara 10,01-13,00, dan $57,10 \%$ mempunyai skor antara 13,01-16,00.
Tabel 23. Keefektifan Penggunaan Media Pembelajaran

\begin{tabular}{cccc}
\hline No & Skor & Kriteria & Persentase \\
\hline 1 & $4,00-7,00$ & Kurang efektif & 0,00 \\
2 & $7,01-10,00$ & Cukup efektif & 14,30 \\
3 & $10,01-13,00$ & Efektif & 14,30 \\
4 & $13,01-16,00$ & Sangat efektif & 71,40 \\
& Jumlah & & 100 \\
\hline
\end{tabular}

Berdasarkan Tabel 23 dapat diketahui bahwa dalam penggunaan media pembelajaran, 14,30\% guru berada dalam kriteria cukup efektif, $14,30 \%$ guru berada dalam kriteria efektif, dan $71,40 \%$ guru berada dalam kriteria sangat efektif. Nilai ratarata (mean) sebesar 13,86 menunjukkan bahwa kemampuan guru dalam penggunaan media pembelajaran termasuk dalam kriteria sangat efektif.

\section{Menutup Kegiatan Pembelajaran}

Pada indikator ini terdapat empat kriteria, yaitu: (1) meninjau kembali materi yang telah dipelajari, (2) memberi kesempatan kepada siswa untuk bertanya dan menjawab pertanyaan, (3) memberikan kesimpulan kegiatan pembelajaran, dan (4) membuat rangkuman materi yang dipelajari. Data hasil penelitian menunjukkan $71,40 \%$ guru mempunyai skor antara 10,01 13,00 dan $28,60 \%$ mempunyai skor antara $13,01-16,00$.

Tabel 24. Keefektifan Menutup Kegiatan Pembelajaran

\begin{tabular}{cccc}
\hline No & Skor & Kriteria & Persentase \\
\hline 1 & $4,00-7,00$ & Kurang efektif & 0,00 \\
2 & $7,01-10,00$ & Cukup efektif & 0,00 \\
3 & $10,01-13,00$ & Efektif & 71,40 \\
4 & $13,01-16,00$ & Sangat efektif & 28,60 \\
& Jumlah & & 100 \\
\hline
\end{tabular}

Berdasarkan Tabel 24 dapat diketahui bahwa dalam menutup kegiatan pembelajaran, $71,40 \%$ guru berada dalam kriteria efektif dan $28,60 \%$ guru berada dalam kriteria sangat efektif. Nilai rata-rata (mean) sebesar 13,14 menunjukkan bahwa kemampuan guru dalam menutup kegiatan pembelajaran termasuk dalam kriteria sangat efektif. 
Melaksanakan Tindak Lanjut

Pada indikator ini terdapat empat kriteria, yaitu: (1) memberikan tugas kepada siswa secara individu maupun kelompok, (2) menginformasikan materi/bahan belajar yang akan dipelajari berikutnya, (3) memberikan motivasi siswa untuk giat belajar, dan (4) bekerjasama dengan orang tua. Data hasil penelitian menunjukkan $71,40 \%$ guru mempunyai skor antara 10,01 13,00 dan $28,60 \%$ guru mempunyai skor antara 13,01-16,00.

Tabel 25. Keefektifan Melaksanakan Tindak Lanjut

\begin{tabular}{cccc}
\hline No & Skor & Kriteria & Persentase \\
\hline 1 & $4,00-7,00$ & Kurang efektif & 0,00 \\
2 & $7,01-10,00$ & Cukup efektif & 0,00 \\
3 & $10,01-13,00$ & Efektif & 71,40 \\
4 & $13,01-16,00$ & Sangat efektif & 28,60 \\
& Jumlah & & 100 \\
\hline
\end{tabular}

Berdasarkan Tabel 25 dapat diketahui bahwa dalam melaksanakan tindak lanjut, $71,40 \%$ guru berada dalam kriteria efektif, dan 28,60\% guru berada dalam kriteria sangat efektif. Nilai rata-rata (mean) sebesar 12,86 menunjukkan bahwa kemampuan guru dalam melaksanakan tindak lanjut termasuk dalam kriteria efektif.

\section{Aspek Penilaian Pembelajaran}

Berikut data penilaian pembelajaran untuk masing-masing indikator:

\section{Merencanakan Penilaian}

Pada indikator ini terdapat tiga kriteria, yaitu: (1) menetapkan kriteria ketuntasan minimal, (2) menyusun kisi-kisi soal, (3) menyusun soal evaluasi. Data hasil penelitian menunjukkan terdapat $28,60 \%$ guru mempunyai skor antara 7,51-9,75 71,40\% guru mempunyai skor antara 9,76-12,00.

Tabel 26. Keefektifan Merencanakan Penilaian

\begin{tabular}{cccc}
\hline No & Skor & Kriteria & Persentase \\
\hline 1 & $3,00-5,25$ & Kurang efektif & 0,00 \\
2 & $5,26-7,50$ & Cukup efektif & 0,00 \\
3 & $7,51-9,75$ & Efektif & 28,60 \\
4 & $9,76-12,00$ & Sangat efektif & 71,40 \\
& Jumlah & & 100 \\
\hline
\end{tabular}

Berdasarkan Tabel 26 dapat diketahui bahwa dalam merencanakan penilaian, terdapat $28,60 \%$ guru berada dalam kriteria efektif dan $71,40 \%$ guru berada dalam kriteria sangat efektif. Nilai rata-rata (mean) sebesar 10,14 menunjukkan bahwa kemampuan guru dalam merencanakan penilaian berada dalam kriteria sangat efektif.

\section{Melaksanakan Penilaian}

Pada indikator ini terdapat empat kriteria, yaitu: (1) melaksanakan penilaian sesuai jumlah KD, (2) menghitung persentase ketuntasan, (3) melakukan analisis hasil penilaian, dan (4) menghitung daya serap secara klasikal.

Data hasil penelitian menunjukkan $28,60 \%$ guru mempunyai skor antara 7,01 $10,00,57,10 \%$ guru mempunyai skor antara $10,01-13,00,14,30 \%$ guru mempunyai skor antara $13,01-16,00$.

Tabel 27. Keefektifan Melaksanakan Penilaian

\begin{tabular}{cccc}
\hline No & Skor & Kriteria & Persentase \\
\hline 1 & $4,00-7,00$ & Kurang efektif & 0,00 \\
2 & $7,01-10,00$ & Cukup efektif & 28,60 \\
3 & $10,01-13,00$ & Efektif & 57,10 \\
4 & $13,01-16,00$ & Sangat efektif & 14,30 \\
\multicolumn{2}{c}{ Jumlah } & 100 \\
\hline
\end{tabular}

Berdasarkan Tabel 27 dapat diketahui bahwa dalam melaksanakan penilaian, $28,60 \%$ guru berada dalam kriteria cukup efektif, $57,10 \%$ guru berada dalam kriteria efektif dan $14,30 \%$ guru berada dalam kriteria sangat efektif. Nilai rata-rata (mean) sebesar 11,71 menunjukkan bahwa kemampuan guru dalam melaksanakan penilaian termasuk dalam kriteria efektif.

\section{Menindaklanjuti Hasil Penilaian}

Pada indikator ini terdapat lima kriteria, yaitu: (1) melaksanakan pembelajaran remedial untuk KD yang ketuntasannya kurang dari 60\%, (2) melaksanakan perbaikan bagi peserta didik yang belum mencapai KKM, (3) melaksanakan pengayaan bagi peserta didik yang sudah mencapai KKM, (4) melakukan analisis butir soal, dan (5) mendokumentasikan hasil penilaian. Data hasil penelitian menunjukkan 
terdapat $28,60 \%$ guru mempunyai skor antara $8,76-12,50$, dan $71,40 \%$ guru mempunyai skor antara $12,51-16,25$.

Tabel 28. Keefektifan Menindaklanjuti Hasil Penilaian

\begin{tabular}{cccc}
\hline No & Skor & Kriteria & Persentase \\
\hline 1 & $5,00-8,75$ & Kurang efektif & 0,00 \\
2 & $8,76-12,50$ & Cukup efektif & 28,60 \\
3 & $12,51-16,25$ & Efektif & 42,90 \\
4 & $16,26-20,00$ & Sangat efektif & 28,60 \\
\multicolumn{2}{c}{ Jumlah } & 100 \\
\hline
\end{tabular}

Berdasarkan Tabel 28 dapat diketahui bahwa dalam menindaklanjuti hasil penilaian, terdapat $28,60 \%$ guru berada dalam kriteria cukup efektif dan $71,40 \%$ guru berada dalam kriteria efektif. Nilai ratarata (mean) sebesar 14,29 menunjukkan bahwa kemampuan guru dalam menindaklanjuti hasil penilaian termasuk dalam kriteria efektif.

Aspek Pengawasan Pembelajaran

Berikut data pengawasan pembelajaran untuk masing-masing indikator:

\section{Pemantauan Pembelajaran}

Pada indikator ini terdapat empat kriteria yang meliputi: menyusun program pengawasan proses pembelajaran, menyiapkan instrumen, menentukan jadwal pemantauan, dan mencermati dokumen pembelajaran. Data hasil penelitian menunjukkan terdapat 22,22\% responden mempunyai skor antara 10,01-13,00 dan 77,78\% responden mempunyai skor antara 13,0116,00 .

Tabel 29. Keefektifan Pemantauan Pembelajaran

\begin{tabular}{cccc}
\hline No & Skor & Kriteria & Persentase \\
\hline 1 & $4,00-7,00$ & Kurang efektif & 0,00 \\
2 & $7,01-10,00$ & Cukup efektif & 0,00 \\
3 & $10,01-13,00$ & Efektif & 22,22 \\
4 & $13,01-16,00$ & Sangat efektif & 77,78 \\
\multicolumn{3}{c}{ Jumlah } & 100 \\
\hline
\end{tabular}

Berdasarkan Tabel 29 dapat diketahui $22,22 \%$ responden menyatakan bahwa pemantauan pembelajaran berada dalam kriteria efektif dan $77,78 \%$ responden menyatakan bahwa pemantauan pembelajar- an berada dalam sangat efektif. Sedangkan nilai rata-rata (mean) sebesar 14,22 menunjukkan bahwa kemampuan kepala sekolah dan pengawas dalam melaksanakan pemantauan pembelajaran sangat efektif.

\section{Supervisi Pembelajaran}

Pada indikator ini terdapat empat kriteria yang meliputi: melakukan kunjungan kelas sesuai kesepakatan, mencocokkan pelaksanaan pembelajaran yang dilakukan oleh guru dengan perencanaan pembelajaran, mengisi instrumen supervisi sesuai hasil pengamatan, dan mendiskusikan hasil supervisi dengan guru yang disupervisi. Data hasil penelitian menunjukkan terdapat $77,78 \%$ responden mempunyai skor antara $10,01-13,00$ dan $22,22 \%$ responden mempunyai skor antara 13,0116,00 .

Tabel 30. Keefektifan Supervisi Pembelajaran

\begin{tabular}{|c|c|c|c|}
\hline No & Skor & Kriteria & Persentase \\
\hline 1 & $4,00-7,00$ & Kurang efektif & 0,00 \\
\hline 2 & $7,01-10,00$ & Cukup efektif & 0,00 \\
\hline 3 & $10,01-13,00$ & Efektif & 77,78 \\
\hline 4 & $13,01-16,00$ & Sangat efektif & 22,22 \\
\hline & \multicolumn{2}{|c|}{ Jumlah } & 100 \\
\hline
\end{tabular}

Berdasarkan Tabel 30 dapat diketahui $77,78 \%$ responden menyatakan bahwa supervisi pembelajaran berada dalam kriteria efektif dan $22,22 \%$ responden menyatakan bahwa supervisi pembelajaran berada dalam kriteria sangat efektif. Nilai rata-rata (mean) sebesar 12,33 menunjukkan bahwa kemampuan kepala sekolah dan pengawas dalam melaksanakan supervisi pembelajaran berada dalam kriteria efektif.

\section{Evaluasi Pembelajaran}

Pada indikator ini terdapat dua kriteria, yaitu: memberikan penilaian sesuai hasil supervisi dan memberikan rekomendasi perbaikan pembelajaran. Data hasil penelitian menunjukkan terdapat $44,44 \%$ responden mempunyai skor antara 5,016,50 dan $55,56 \%$ responden mempunyai skor antara 6,51-8.00.

Berdasarkan Tabel 31 dapat diketahui $44,44 \%$ responden menyatakan bahwa 
evaluasi pembelajaran berada dalam kriteria efektif dan 55,56\% responden menyatakan bahwa evaluasi pembelajaran berada dalam kriteria sangat efektif. Nilai rata-rata (mean) sebesar 6,56 menunjukkan bahwa kemampuan kepala sekolah dan pengawas dalam melaksanakan evaluasi pembelajaran berada dalam kriteria sangat efektif.

Tabel 31. Keefektifan Evaluasi Pembelajaran

\begin{tabular}{cccc}
\hline No & Skor & Kriteria & Persentase \\
\hline 1 & $2,00-3,50$ & Kurang efektif & 0,00 \\
2 & $3,51-5,00$ & Cukup efektif & 0,00 \\
3 & $5,01-6,50$ & Efektif & 44,44 \\
4 & $6,51-8,00$ & Sangat efektif & 55,56 \\
\multicolumn{2}{c}{ Jumlah } & 100 \\
\hline
\end{tabular}

Pelaporan Hasil Supervisi

Pada indikator ini terdapat empat kriteria yang meliputi: menyiapkan format laporan pengawasan proses pembelajaran, menyusun laporan sesuai hasil supervisi, mendokumentasikan laporan hasil supervisi, dan menyampaikan laporan hasil supervisi kepada pihak terkait. Data hasil penelitian menunjukkan $100 \%$ responden mempunyai skor antara 13,01-16,00.

Tabel 32. Keefektifan Pelaporan Supervisi

\begin{tabular}{cccc}
\hline No & Skor & Kriteria & Persentase \\
\hline 1 & $4,00-7,00$ & Kurang efektif & 0,00 \\
2 & $7,01-10,00$ & Cukup efektif & 0,00 \\
3 & $10,01-13,00$ & Efektif & 0,00 \\
4 & $13,01-16,00$ & Sangat efektif & 100 \\
\multicolumn{2}{c}{ Jumlah } & 100 \\
\hline
\end{tabular}

Berdasarkan Tabel 32 dapat diketahui $100 \%$ responden menyatakan bahwa pelaporan hasil supervisi berada dalam kriteria sangat efektif. Nilai rata-rata (mean) sebesar 15,33 juga menunjukkan bahwa kemampuan kepala sekolah dan pengawas dalam melaksanakan pelaporan hasil supervisi berada dalam kriteria sangat efektif.

\section{Tindak Lanjut Hasil Supervisi}

Pada indikator ini terdapat dua kriteria, yaitu: merencanakan kegiatan tindak lanjut hasil supervisi dan melaksanakan tindak lanjut secara langsung atau melalui KKG. Data hasil penelitian menunjukkan terdapat $33,33 \%$ responden mempunyai skor antara 3,51-5,00, 44,45\% responden mempunyai skor antara 5,01-6,50 dan $22,22 \%$ mempunyai skor antara 6,51-8.00.

Tabel 33. Keefektifan Tindak Lanjut Supervisi

\begin{tabular}{cccc}
\hline No & Skor & Kriteria & Persentase \\
\hline 1 & $2,00-3,50$ & Kurang efektif & 0,00 \\
2 & $3,51-5,00$ & Cukup efektif & 33,33 \\
3 & $5,01-6,50$ & Efektif & 44,45 \\
4 & $6,51-8,00$ & Sangat efektif & 22,22 \\
\multicolumn{3}{c}{ Jumlah } & 100 \\
\hline
\end{tabular}

Berdasarkan tabel 33 dapat diketahui $33,33 \%$ responden menyatakan bahwa tindak lanjut hasil supervisi berada dalam kriteria cukup efektif, $44,45 \%$ responden menyatakan efektif, dan $22,22 \%$ menyatakan sangat efektif. Nilai rata-rata (mean) sebesar 6,00 menunjukkan bahwa kemampuan kepala sekolah dan pengawas dalam melaksanakan tindak lanjut hasil supervisi berada dalam kriteria efektif.

\section{Pembahasan}

Pendidikan bermutu merupakan sarana yang penting bagi upaya mencerdaskan kehidupan bangsa dan meraih kehidupan yang lebih baik. Pendidikan bermutu diharapkan mampu mengembangkan potensi diri menjadi insan yang kreatif, mandiri, dan beretos kerja tinggi. Pendidikan bermutu merupakan sarana untuk memberikan bekal kehidupan. Upaya untuk meningkatkan mutu pendidikan antara lain dilakukan dengan penetapan Standar Nasional Pendidikan yang meliputi: Standar Kompetensi Lulusan, Standar Isi, Standar Proses, Standar Pendidik dan Tenaga Kependidikan, Standar Sarana dan Prasarana, Standar Pengelolaan, Standar Pembiayaan, dan Standar Penilaian Pendidikan.

Penjaminan mutu yang dilaksanakan SDN Kaliurang 2 Kecamatan Pakem, merupakan komitmen warga sekolah dalam melaksanakan amanat Permendiknas Nomor 63 Tahun 2009 pasal 5, bahwa penjaminan mutu pendidikan formal dan nonformal dilaksanakan oleh satuan atau program pendidikan. Penjaminan mutu standar proses dilaksanakan untuk menjamin ter- 
selenggaranya proses pembelajaran yang efektif dalam rangka meningkatkan mutu pendidikan secara berkesinambungan.

Penjaminan mutu pada standar proses pembelajaran menjadi prioritas utama di SDN Kaliurang 2 Pakem kabupaten Sleman mengingat proses pembelajaran merupakan inti dari kegiatan pendidikan di sekolah. Hal ini sesuai dengan pendapat Hoy \& Miskel (2008, p. 41) yang menyatakan "The technical core of all schools is teaching and learning". Inti teknis dari semua kegiatan di sekolah adalah belajar dan mengajar. Proses pembelajaran perlu direncanakan, dilaksanakan, dinilai, dan diawasi agar terlaksana dengan efektif.

\section{Aspek Perencanaan Pembelajaran}

Berdasarkan deskripsi data hasil penelitian, pelaksanaan penjaminan mutu pada aspek perencanaan pembelajaran secara umum termasuk dalam kriteria sangat efektif meskipun masih terdapat tiga indikator yang berada dalam kriteria efektif. Kesenjangan antara pelaksanaan dengan kriteria standar proses pembelajaran pada aspek perencanaan pembelajaran yang terbesar pada indikator menentukan jenis penilaian. Kriteria yang ditetapkan dalam Permendiknas Nomor 41 tahun 2007 untuk indikator menentukan jenis penilaian, meliputi: (1) jenis penilaian dan instrumen yang digunakan tepat untuk menilai ketercapaian indikator, (2) jenis penilaian dipilih berdasarkan acuan kiteria, (3) mencantumkan KKM KD, dan (4) mencantumkan teknik penskoran.

Dalam pelaksanaannya, hampir semua guru sudah menyusun perencanaan pembelajaran secara optimal, meskipun dalam menentukan jenis penilaian perlu ditingkatkan. Masih terdapat beberapa guru yang belum mencantumkan kriteria ketuntasan minimal (KKM) kompetensi dasar, tetapi mencantumkan KKM mata pelajaran secara umum.

\section{Aspek Pelaksanaan Proses Pembelajaran}

Berdasarkan deskripsi data hasil penelitian, pelaksanaan penjaminan mutu pada aspek pelaksanaan proses pembelajaran secara umum termasuk dalam kriteria sangat efektif meskipun masih terdapat satu indikator yang berada dalam kriteria efektif. Kesenjangan antara pelaksanaan dengan kriteria standar proses pembelajaran pada aspek pelaksanaan proses pembelajaran yang terbesar pada indikator melaksanakan tindak lanjut. Kriteria yang ditetapkan dalam Permendiknas Nomor 41 tahun 2007 untuk indikator melaksanakan tindak lanjut, meliputi: (1) memberikan tugas kepada siswa secara individu maupun kelompok, (2) menginformasikan materi/bahan belajar yang akan dipelajari berikutnya, (3) memberikan motivasi siswa untuk giat belajar, dan (4) bekerjasama dengan orangtua.

Dalam pelaksanaannya, hampir semua guru sudah melaksanakan proses pembelajaran secara optimal, meskipun dalam melaksanakan tindak lanjut perlu ditingkatkan. Materi/bahan belajar yang akan dipelajari pada pertemuan berikutnya perlu diinformasikan kepada siswa dan perlu menjalin kerjasama dengan orangtua dalam hal pendampingan belajar di rumah.

Aspek Penilaian Pembelajaran

Berdasarkan deskripsi data hasil penelitian, pelaksanaan penjaminan mutu pada aspek penilaian pembelajaran secara umum termasuk dalam kriteria efektif. Kesenjangan antara pelaksanaan dengan kriteria standar proses pembelajaran pada aspek penilaian pembelajaran yang terbesar pada indikator menindaklanjuti hasil penilaian. Kriteria yang ditetapkan dalam Permendiknas Nomor 41 tahun 2007 untuk indikator menindaklanjuti hasil penilaian, meliputi: (1) melaksanakan pembelajaran remedial untuk KD yang ketuntasannya kurang dari $60 \%$, (2) melaksanakan perbaikan bagi peserta didik yang belum mencapai KKM, (3) melaksanakan pengayaan bagi peserta didik yang sudah mencapai KKM, (4) melakukan analisis butir soal untuk menentukan validitas isi, dan (5) mendokumentasikan hasil penilaian.

Dalam pelaksanaannya, hampir semua guru sudah melaksanakan perencanaan penilaian dan melaksanakan penilaian, 
dengan optimal, meskipun untuk menindaklanjuti hasil penilaian dalam hal menganalisis butir soal untuk menentukan validitas isi perlu ditingkatkan.

\section{Aspek Pengawasan Pembelajaran}

Berdasarkan deskripsi data hasil penelitian, pelaksanaan penjaminan mutu pada aspek pengawasan pembelajaran secara umum termasuk dalam kriteria sangat efektif. Kesenjangan antara pelaksanaan dengan kriteria standar proses pembelajaran pada aspek pengawasan pembelajaran yang terbesar pada indikator tindak lanjut hasil supervisi. Kriteria yang ditetapkan dalam Permendiknas Nomor 41 tahun 2007 untuk indikator tindak lanjut hasil supervisi, meliputi: merencanakan kegiatan tindak lanjut hasil supervisi dan melaksanakan tindak lanjut hasil supervisi secara langsung atau melalui KKG.

Dalam pelaksanaannya, kepala sekolah sudah melaksanakan pemantauan pembelajaran, supervisi pembelajaran, evaluasi pembelajaran, dan pelaporan hasil supervisi secara optimal meskipun dalam melaksanakan tindak lanjut hasil supervisi perlu ditingkatkan.

\section{Penjaminan Mutu Standar Proses}

Berdasarkan deskripsi data hasil penelitian, pelaksanaan penjaminan mutu standar proses pembelajaran secara umum termasuk dalam kriteria sangat efektif. Kesenjangan antara pelaksanaan dengan kriteria standar proses pembelajaran yang terbesar pada aspek penilaian pembelajaran. Indikator yang ditetapkan dalam Permendiknas Nomor 41 tahun 2007 untuk aspek penilaian pembelajaran, meliputi: merencanakan penilaian, melaksanakan penilaian, dan menindaklanjuti hasil penilaian.

Dalam pelaksanaannya, perencanan pembelajaran, pelaksanaan proses pembelajaran, dan pengawasan pembelajaran sudah dilaksanakan secara optimal meskipun penilaian pembelajaran, khususnya dalam menindaklanjuti hasil penilaian perlu ditingkatkan.

\section{Simpulan dan Saran}

Simpulan

Penjaminan mutu standar proses pada aspek perencanaan pembelajaran berada dalam kriteria sangat efektif dengan capaian $85,24 \%$, artinya tingkat kesesuaian antara pelaksanaan dengan standar yang ditetapkan mencapai 85,24\%. Aspek pelaksanaan proses pembelajaran berada dalam kriteria sangat efektif dengan capaian $88,67 \%$, artinya tingkat kesesuaian antara pelaksanaan dengan standar yang ditetapkan mencapai $88,67 \%$. Aspek penilaian pembelajaran berada dalam kriteria efektif dengan capaian $75,29 \%$, artinya tingkat kesesuaian antara pelaksanaan dengan standar yang ditetapkan mencapai 75,29\%. Aspek pengawasan pembelajaran berada dalam kriteria sangat efektif dengan capaian $85,06 \%$, artinya tingkat kesesuaian antara pelaksanaan dengan standar yang ditetapkan mencapai 85,06\%.

Secara umum, penjaminan mutu standar proses di SDN Kaliurang $2 \mathrm{Ke}-$ camatan Pakem, kabupaten Sleman berada dalam kriteria sangat efektif dengan capaian $83,56 \%$, artinya tingkat kesesuaian antara pelaksanaan dengan standar yang ditetapkan mencapai $83,56 \%$.

Saran

Berdasarkan simpulan hasil penelitian, disarankan kepada kepala sekolah untuk meningkatkan mutu pendidikan di sekolah dengan melaksanakan penjaminan mutu pada standar yang lain dan kepada guru disarankan untuk meningkatkan kemampuan dalam aspek penilaian pembelajaran. Kepada peneliti lanjutan disarankan untuk melakukan penelitian dengan kajian yang lebih mendalam tentang keefektifan penjaminan mutu pendidikan, misalnya pengaruh penjaminan mutu pendidikan terhadap prestasi belajar siswa dan animo masyarakat.

\section{Daftar Pustaka}

Depdiknas. (2007). Peraturan Menteri Pendidikan Nasional Republik Indonesia 
Nomor 41, Tahun 2007, tentang Standar Proses untuk Satuan Pendidikan Dasar dan Menengah.

Depdiknas. (2009). Peraturan Menteri Pendidikan Nasional Republik Indonesia Nomor 63, Tahun 2009, tentang Sistem Penjaminan Mutu Pendidikan.

Direktorat Pembinaan SMA. (2010). Juknis penyusunan perangkat penilaian di SMA. Diakses pada tanggal 28 Februari 2014, dari teguhsasmitosdp1.files.wordpress.c om/2010/06/30-juknis-penilaianafektif_isi-revisi_0104.pdf

Hoy, W. K. \& Miskel, C. G. (2008). Educational administration: Theory, research, and practice. McGraw-Hill Education.

Kardiyem. (2013). Analisis kinerja guru pascasertifikasi: Studi empiris pada guru akutansi SMK se-Kabupaten Grobogan. Journal of Economic Education. Diakses pada tanggal 7 September 2013, dari http://journal.unnes.ac.id/sju/ind ex.php/jeec/article/download/270 $\underline{4 / 2492}$

Raharjo, S. B. (2013). Evaluasi trend kualitas pendidikan di indonesia. Jurnal Penelitian dan Evaluasi Pendidikan, 16(2), 511-532. Retrieved from http://journal.uny.ac.id/index.php Lipep/article/view/1129/2819

Republik Indonesia. (2013). Peraturan Pemerintah Republik Indonesia Nomor 32, Tahun 2013, tentang Perubahan atas Peraturan Pemerintah Nomor 19 Tahun 2005, tentang Standar Nasional Pendidikan. 